\title{
PENINGKATAN MINAT BERINVESTASI MELALUI LITERASI KEUANGAN PASAR MODAL
}

\author{
Debbi Chyntia Ovami ${ }^{1)}$, Anggia Sari Lubis ${ }^{2)}$ \\ Universitas Muslim Nusantara Al-Washliyah Medan ${ }^{1)}$ \\ Universitas Muslim Nusantara Al-Washliyah Medan²) \\ debbichyntiaovami@umnaw.ac.id \\ anggiasarilubis@umnaw.ac.id
}

\begin{abstract}
ABSTRAK
Tujuan dari kegiatan Program Layanan Masyarakat melalui PKM (Program Kemitraan Masyarakat) adalah untuk meningkatkan kesadaran, ketertarikan dan pengetahuan siswa mengenai literasi keuangan pasar modal. Mitra kegiatan pengabdian kepada masyrakat ini adalah siswa SMK Swasta Al Washliyah 3 Medan yang berada di jalan Garu II Medan. Permasalahan mitra yaitu ketidaktahuan siswa tentang pasar modal, kurangnya kesadaran dan tertarik dengan investasi yang bersifat jangka panjang. Solusi yang akan dilakukan dalam Program IBM ini adalah sosialisasi untuk peningkatan pengetahuan akan pasar modal dan kesadaran serta menumbuhkan ketertarikan untuk berinvestasi jangka panjang sejak muda. Metode yang diterapkan adalah klasikal dan individual. Metode pendekatan ini dalam bentuk ceramah dan praktek. Pendekatan individual dilakukan pada saat praktek berupa memberi sosialisasi pengetahuan mengenai literasi keuangan pasar modal serta meningkatkan kesadaran dan ketertarikan siswa dalam berinvestasi di pasar modal. Hasil yang diperoleh yaitu para guru dapat meningkatkan pemahaman dan pengetahuan tentang pasar modal serta kesadaran dan ketertarikan guru terhadap investasi dalam pasar modal.
\end{abstract}

Kata kunci: minat investasi, literasi keuangan, pasar modal

\begin{abstract}
The objective of the Community Service Program through PKM (Community Partnership Program) is to increase students' awareness, interest and knowledge regarding capital market financial literacy. This community service partner is a student of the Al Washliyah 3 Medan Vocational High School which is on Jalan Garu II Medan. Partner problems are students' ignorance of the capital market, lack of awareness and interest in long-term investments. The solution that will be carried out in this IBM Program is socialization to increase knowledge of the capital market and awareness and to foster interest in long-term investing from young. The methods applied are classical and individual. This approach method takes the form of lectures and practices. An individual approach is taken during practice in the form of providing knowledge dissemination about capital market financial literacy and increasing students' awareness and interest in investing in the capital market. The results obtained are that teachers can increase their understanding and knowledge of the capital market as well as teachers' awareness and interest in investing in the capital market.
\end{abstract}

Keywords: interest in investment, financial literacy, capital market

\section{PENDAHULUAN}

Pertumbuhan penduduk selalu dikaitkan dengan pertumbuhan ekonomi. Seperti yang terjadi di Indonesia, dengan adanya peningkatan pertumbuhan ekonomi, maka potensi perusahaan perusahaan untuk berkembangan semakin meningkat baik dari lembaga keuangan maupun non keuangan. Tetapi yang paling utama ada berdampak terhadap pertumbuhan ekonomi adalah perusahan keuangan. Untuk itu diperlukan hubungan yang baik antara masyarakat dengan industri jasa keuangan (S, 2017). Jumlah investor pasar modal Indonesia yang tercatat di PT Kustodian Sentral Efek Indonesia (KSEI) per Juli 2020 mencapai 3,02 juta investor atau tumbuh $17,8 \%$ dari akhir tahun 2019 lalu yang tercatat 
2,48 juta investor. Jika dibandingkan tahun 2016 yang sebanyak 894.000 investor maka jumlahnya meningkat 3,4 kali lipat. Direktur Utama Kustodian Sentral Efek Indonesia Uriep Budhi Prasetyo merinci, jumlah investor tersebut sebanyak 46,14\% merupakan investor di bawah umur 30 tahun, meningkat dari kondisi tahun lalu yang hanya sekitar $44 \%$. Direktur Utama Bursa Efek Indonesia (BEI) Inarno Djajadi menambahkan, kondisi pandemi Covid-19 ternyata tidak menyurutkan minat investor untuk bertransaksi saham (www.investasi.kontan.co.id). Berdasarkan hasil Survei Nasional Literasi dan Inklusi Keuangan (SNLIK) tahun 2016 yang dilakukan Otoritas Jasa Keuangan (OJK) menyebutkan indeks literasi keuangan di tahun 2016 sebesar $29,66 \%$ dan indeks inklusi keuangan sebesar $67,82 \%$. Hal ini mengalami peningkatan dibandingkan tahun 2013.Berdasarkan data dari yuk nabung saham diketahui indeks literasi secara sektoral menempatkan indeks literasi pasar modal di urutan terbawah yaitu sebesar $4.40 \%$ kemudian diikuti oleh literasi dana pensiun sebesar $10.91 \%$ dan indeks literasi tentang lembaga pembiayaan sebesar $13.05 \%$. angka tersebut tentunya masih sangat jauh dibandingkan dengan target OJK. Berdasarkan Peraturan Presiden Republik Indonesia Nomor 82 tahun 2016 tentang Strategi Nasional Keuangan Inklusif (SNKI) adalah sebesar $75 \%$ di tahun 2019. Maka dari itu, diperlukan adanya pengenalan pasar modal sejak dini untuk merubah pola dari saving society menjadi investing society (Windasari \& Zakiyah, 2020).

$$
\text { Kegiatan edukasi dan }
$$
sosialisasi mengenai pasar modal belum pernah dilakukan di SMK Swasta Al Washliyah 3 medan, hal ini dapat dilihat dari rendahnya pengetahuan siswa mengenai pasar modal, bahkan ada beberapa peserta didik tidak mengetahui sama sekali. Selama ini peserta didik hanya mengetahui investasi itu dengan menabung di bank. Hal ini yang mendorong pengabdi untuk melakukan kegiatan sosialisasi literasi keuangan pasar modal dalam meningkatkan minat berinvestasi di SMK Swasta Al Washliyah 3 Medan. SMK Swasta Al Washliyah 3 Medan berada di J1 Garu 2 No 92 Kelurahan Harjosari.

\section{METODE PELAKSANAAN}

Metode pelaksanaan untuk kegiatan pengabdian kepada masyarakat di SMK Swasta Al Washliyah 3 Medan adalah sebagai berikut:

1. Memberikan pengetahuan pasar modal kepada siswa dan guru

Peserta diberikan pengetahuan tentang seberapa pentingnya pasar modal untuk berinvestasi terutama bagi siswadan guru

2. Membangkitkan/ meningkatkan kesadaran, dan ketertarikan siswa dan guru

Peserta diberikan motivasi atau dorongan atas pentingnya literasi keuangan pasar modal untuk berinvestasi. Kemudian diberikan contoh produk pasar modal dan mekanisme perdagangannya .

Alternatif pemecahan masalah dalam permasalahan mitra dilakukan pendampingan dengan dua pendekatan, yakni pendekatan klasikal dan individual. Pendekatan klasikal dilakukan pada saat penyampaian materi. Pendekatan 
individual dilakukan pada saat praktek, yaitu menmbangkitkan kesadaran, ketertarikan dan pengetahuan siswa dan guru untuk berinvestasi

\section{HASIL DAN PEMBAHASAN}

Kegiatan Pengabdian kepada masyarakat dilaksanakan di SMK Swasta Al Washliyah 3. Kegiatan ini disambut dengan baik oleh Kepala Sekolah, wakil kepala sekolah, guru dan siswa di sekolah tersebut. Kegiatan pengabdian ini dimulai dari persiapan : pengadaan sekaligus penggandaan modul, sosialisasi program, penentuan lokasi, waktu dan tempat kegiatan dan kegiatan inti yakni sosialisasi literasi keuangan pasar modal bagi guru dan siswa. Para peserta sangat antusias dalam kegiatan ini, hal ini dibuktikan dengan peserta yang menghadiri pengabdian sebanyak 10 orang .

Dalam pengabdian masyarakat, guru dan siswa ini masih belum mengetahui dan memahami investasi dan pasar modal. Guru dan siswa tersebut hanya mendengarkan sekilas mengenai investasi pasar modal. Kemudian para guru dan siswa selama ini hanya melakukan invetasi jangka pendek seperti pembelian aktiva tetap dan emas. Selain itu mindset para guru dan siswa bahwasanya investasi membutuhkan modal besar.

Hasil pengabdian kepada masyarakat yang sudah dilakukan, yaitu :

1. Timbulnya motivasi dan kesadaran diri dari para guru dan siswa, bahwasanya investasi jangka panjang sangat penting

2. Pemahaman para guru dan siswa terhadap jenis - jenis investasi dan produk - produk pasar modal
3. Pemahaman para guru dan siswa terhadap mekanisme perdagangan pasar modal

4. Kegiatan pelatihan ini tidak hanya satu arah, tetapi terjadi dua arah dengan adanya sesi diskusi. Diskusi berlangsung setelah penyampaian materi dengan tertib dan terarah.
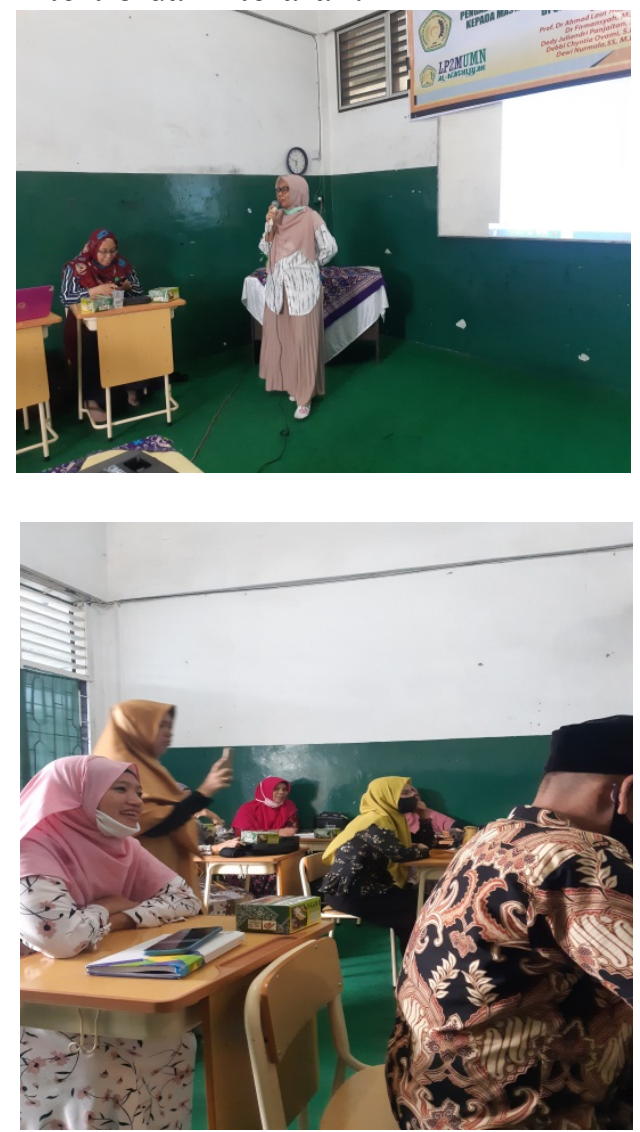

Gambar 5.1 Proses PKM

\section{Dampak Ekonomi dan Sosial}

Dampak ekonomi yang diperoleh dari kegiatan pengabdian kepada masyarakat ini adalah dengan berinvestasi dalam pasar modal, para guru dan siswa dapat meningkatkan pendapatan untuk kebutuhan hidup masing - masing baik harian ataupun jangka panjang. Perencanaan atau keinginan yang diharapkan dapat tercapai dengan ikut bergabung investasi dalam pasar modal. 
Dampak sosial yang diperoleh adalah dapat meningkatkan derajata/ martabat atau status sosial jika mendapatkan penghasilan yang berlebih dari kegiatan investasi ini.

\section{KESIMPULAN}

Kegiatan pengabdian kepada masyarakat yang dilaksanakan di SMK Swasta Al Washliyah 3 medan telah berjalan dengan lancar dan para guru dan siwa sangat antusias terhadap kegiatan tersebut. Kegiatan ini menambah motivasi, wawasan dan pemahaman mengenai literasi keuangan pasar modal demi kemajuan dan kelangsungan pendapatan kedepannya. Selain itu para guru dan siswa berminat untuk berinvestasi dalam pasar modal. Sebagai penunjang kegiatan pengabdian masyarakat ini, pihak sekolah disarankan untuk bersedia membuat kegiatan sepeeti seminar atau workshop pasar modal untuk meningkatkan minat investasi dalam pasar modal dan menjadikan pasar modal sebagai mata pelajaran tunggal / insersi dalam kurikulum sekolah.

\section{REFERENSI}

S, Y. S. (2017). Pengaruh Motivasi dan Literasi Keuangan terhadap Minat Berinvestasi di Pasar Modal (Studi Kasus Mahasiswa Universitas Muhammadiyah Purwokerto). JPA, 18(2), 290-301.

Windasari, W., \& Zakiyah, T. (2020). Literasi Investasi Bagi Generasi Milenial di Era Digital. Journal of Community Service and Empowerment, 1(1).

www. investasi.kontan.co.id 